\title{
Challenges for Indian Entry into Organisation of Islamic Countries (OIC)
}

Fariha Ahmad Hashmi

Research Scholar, Department of International Relations, NDU, Sialkot, Pakistan.

Dr Muhammad Imran Rashid

Assistant Professor/ Head, Department of International Relations, University of Sialkot, Pakistan

\section{KEYWOR D S}

\section{Atrocities}

Rebut

OIC

India

Pakistan

Kashmir

Saudi Arabia

ICFM

Image.

D A T E S

\section{AB S T R A C T}

Enough of humiliation and what India calls as defaming by the resolutions by OIC on Kashmir, India has dealt with the challenges it had to face to enter into OIC. The tale of challenges faced by India, and the reciprocal attitude of New Delhi is a concrete depiction of international politics based on national interests, and where International organizations voice for human rights but get overpowered by individual member's national interests. This piece of paper encompasses a show of challenges what India had to face, could overcome them and how creating challenges for its rivals.

DOI: $\underline{\text { https://doi.org/10.54064/negotiations.v1i2.19 }}$

\section{QR CODE}

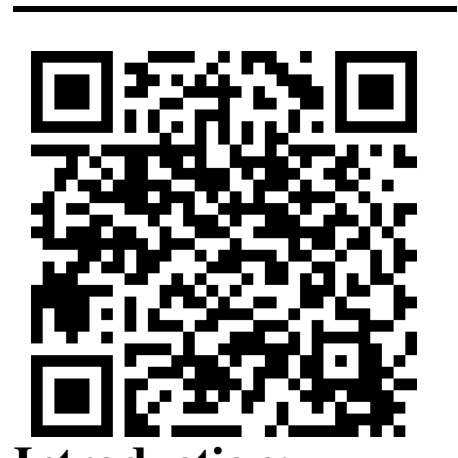

Introduction:

Organization of Islamic Cooperation, known as OIC is the second largest Intergovernmental Organization after United Nations Organization, mainly having 57 Muslim states as members. OIC is mainly known as an organization of Islamic States, having Muslim States as members, but this 
respective organization has some non-Muslim majority countries as its part, for instance Russia and Thailand which enjoy the observer status in OIC.

Organization of Islamic Cooperation chants for the solidarity of Muslim Ummah and tends to make efforts for the betterment of conditions of Muslims around the world. The organization that viewed and had the issue of Palestine as the base for the establishment of OIC in 1969, apparently was about the state and the rights of Palestinian Muslims vis-à-vis Israeli occupation. However, in analytical means, it just took Palestine issue an initiative to formally launch the organization, and keep putting effort on international level for the sake of betterment of Muslims around the world.

Having 57 members into OIC, the organization covers 1.8 billion population. The preamble of OIC where advocates and envisions to become the voice of Muslims around the globe, and for that matter OIC has given observer status to those states where there is Muslim minority. Here lies the question about Indian inclusion into the OIC, that was to be one of the original members of the organization in 1969, but history says that Pakistan's objections did not let it happen. Regardless of the fact that Indian is the home of 201 million Muslims that makes 11 percent of the total Indian population, hence makes India the largest Muslim-minority country.

After the humiliation that India had to face in Rabat (Morocco) in 1969 summit, did not try to get the membership. However, there has always remained a kind of aspiration and a desire to be there at the forum of Organization of Islamic Cooperation. If not in the past, then surely in recent times, under Prime Minister Narendra Modi's vision of global outreach- India desires to be there in OIC, whether as a member or the observer state. Many scholars or analysts may not agree with this respective claim, but the excitement that was showed by the External Affairs Ministry in 2019, after receiving an invite from Abu Dhabi, to attend the $46^{\text {th }}$ session of The Council of Foreign Ministers as "Guest of Honor", indicates that there is something that India wants to achieve at OIC. Moreover, in the backdrop of the humiliation caused by Pakistan in the first ever session of OIC in Rabat, Pakistan's continuous claim of Indian occupation of Kashmir, Indian atrocities and bad conditions of Muslims of India, along with a series of resolutions passed against Indian occupation and the treatment to Muslims there- India claims that the OIC is highly influenced by the Pakistan's perspective of India. The hurdle in the Indian way to OIC is mainly Pakistan and its narrative towards India, while a different opinions prevail in Indian constituencies on the question, whether India should go for entry into OIC, or not as it will shatter India's secular image and will label her 
as Muslim State. However, on the other hand another opinion that can be found in the literature is that India's unique stature is required to be understood as it has the third largest Muslim population and is the largest Muslim Minority country as narrated earlier.

This piece of paper aims at elaborating the reasons for why India and mainly its scholars who write on the issue are eager to get into the OIC and what interest are hidden into their respective desire. The aspirations of Prime Minister Narendra Modi include becoming an economic giant, industrial hub, recognition as the big power, influential power throughout the globe and other strategic ambitions. While all this needs to have a massive economy, for this is required trade, energy and fuel. India is getting all of them as is an essential partner of the Gulf States especially, Kingdom of Saudi Arabia and United Arab Emirates. This might be the reason for why UAE invited India, knowing the fury in Pakistan over this invite into $46^{\text {th }}$ session of The Council of Foreign Ministers that held in March, 2019.

Indian leadership's inspirations, aspirations and ambitions are clear in a way when they are engaged into cordial strategic ties with Gulf countries, which invite them to the OIC, its desire to isolate Pakistan on International forums, containing Pakistan's anti-India approach which is dominant in OIC and reflects through the resolutions passed by OIC over Kashmir issue. Simultaneously, on the other hand there is a faction skeptic about Indian entry into OIC. Apprehensions that circulate are if India gets its way towards and into OIC then OIC may attempt to enforce its verdict regarding Kashmir on India. OIC can enforce New Delhi to permit the OIC delegation to visit the Valley and conditions there that is surely not in India's interests. Another concern that exists is the distortion of India's secular image.

This piece of paper intends to look into what challenges India faces at this forum, is it just Pakistan or the Indian policies which halt its path towards OIC? By going through the history briefly, the current situation of Indian atrocities in IHK, and in India- this paper aims to highlight the points where New Delhi needs to focus in order to get its image clear. Already not only countries in West Asia but also India's eastern neighbour Bangladesh desires for reforms that should allow India to be the part of the OIC, as its presence cannot be ignored anymore just because of Pakistan and also because of the fact that it is not Muslim majority country. Discussing the challenges of Indian entry into OIC in the context of recent atrocities and happening, Indo-Gulf engagements, the paper aims to highlight and analyse the future prospects if Pakistan keeps 
standing on its stance, and rest of the members chant to have India into OIC, moreover discussing the chances of fragmentation of OIC.

\section{Literature Review:}

"OIC: An Examination of its policies and Implications for India" by Anwar Alam is all about what OIC was aimed to do, how to do and overviewing the resolutions that were passed for the giving their sort of verdict on Palestine, Kashmir issue and others. One of the purpose of OIC that it did not aimed at becoming Islamic organization but another international forum having Muslim countries as members. India neither being a Muslim state, nor a Muslim Majority state, yet having second largest Muslim population of the world, how can approach OIC, what conditions they face, India's argument over their previous humiliation in Rabat (1969), its secularity, and willingness to come into OIC is all what a reader can find in this document. The debacle of Rabat, Pakistan pushing OIC to work on Kashmir issue infuriated the Indian policy maker, with the fear of being labelled as Muslim state thus shattering the Indian and Hindu interests of the previous politicians. The article in the ending paragraphs discusses the Indian concerns saying OIC is not Pakistan's organization only, and India can register its dissent over OIC's resolutions on Kashmir. The thing that could be discussed here is the viewpoint of majority in India, do they want to be a part of OIC to contain Pakistan's narrative and anti-Indian resolutions on Kashmir.

The article "Indo-OIC Relations Perspective and Trend-I" by A.K. Pasha elaborates the historical context of Indo-OIC ties. Where at the one place it comprehensively takes a view of the resolutions passed by OIC against India and its misconducts in Kashmir, Ayodhya (Babri Masjid) and the incident of Hazuribagh shrine, simultaneously discusses Indian reactions on these respective resolutions which are passed every now and then against India. The author claims in the article that OIC is highly influenced by the Pakistan's narrative on Kashmir, and causing damage to Indian image. Meanwhile the article advocates Indian presence in the OIC as a secular state, and also describes Indian stance for why she has been negating OIC's resolutions, offers of mediation, and its concerns for Indian Muslims, saying that OIC has no right to debate over the issue when they have rebuffed India at the first Summit in Rabat, and also OIC didn't care about Indian Muslims at that time. The claim has been made that OIC works as agency responsible for the advocacy of Pakistan on International fora, defaming India, causing strain in ties (political, economic and diplomatic) with the Muslim world eventually, that are obviously not in Indian interests. However, the article could have chosen to take an unbiased stance in the debate and 
discussed that how Indian acts, its behaviour, and refusal to allow OIC's missions to visit Kashmir added fuel to the fire. However, there is much more in the box which is being conceded by New Delhi, and one cannot always put the blame on Pakistan only.

Vinay Barkane in his article titles as "India's Strategic Interests in the West Asian Region" is a comprehensive summery of India's plan of action. The article starts with the background of what constraints India had to face and impressively depicts the resilience and passion of making India great. Acknowledging India's weak posture in the Gulf, and the strained ties with the Gulf States, article is all about the vision, foreign policy and the efforts made by former Prime Minister P. V. Narsimha Rao to present day Prime Minister Narendra Modi to conquer the former hostile states, and establish concrete strategic, political, diplomatic and economic ties. Where the Arab states were initially influenced by Pakistan's perspective of India, should be approached and bilateral ties based on mutual interests should be established. Where the article discusses warm ties with the all states of GCC, and accepts the challenge posed by Pakistan in OIC, author could have elaborated Indo- Arab ties in context of OIC, and discuss how the bilateral ties with these Arab nations will help, assist and support in OIC.

Rhea Chakraborty in "India becomes first non-Islamic nation to attend OIC: Find out what this means" shares her views about India's presence at the OIC's meeting of Council of Foreign Minister held in 2019. The article says that Indian presence there in OIC has put Pakistan on defensive position. Since Qatar is advocate of Indian presence in OIC as observer since 2002, Bangladesh also came out in India's support in year 2018. Warm ties with Gulf nations is important and the OIC is the mean. The invite as "Guest of Honor" from the host country is an opportunity by using which India can contain Pakistan's anti India narrative. The thing that could be there and would have helped the article emerge out as a more unbiased one, if the possible Pakistani response has been discussed. Is it this easy for India to use OIC to push Pakistan at defensive position? And build ties with other members, while knowing that Pakistan is the only Muslim nuclear state and is a founding member of the organization, and its importance cannot be neglected easily.

“OIC's India Venture: Diplomatic Achievement for India?" by Prof. Abdullahi Ahsan, is an attempt to clarify the course for history and describes what actually happened at Rabat Summit of 1969. Author clarifies Pakistan's position as she has been being blamed for rebuffing of India at the $1^{\text {st }}$ Summit of OIC, while the contention was caused on the issue of not allowing a Sikh to represent the Muslims of India when there are bulging Indian atrocities against Muslims there. The 
article opines that India has reached the organization knowing its importance in strategic terms, but stickiness to this forum, future policies and for the achievement of Indian interests, it is essential for India to stay humble.

\section{Hypothesis:}

Refrained Indo-Pak ties, India's treatment to Muslim minorities, atrocities in Kashmir along with other concerns raised by Pakistan have always been a constraint in India's way to OIC. However, the challenges are not challenging anymore, as India could become able to attend meeting in OIC. Additionally, Indian atrocities are here to remain even if India gets entry to OIC, because of the Indo-Gulf economic, strategic and diplomatic mutuality of interests and engagements in these respective departments.

\section{Research Questions:}

What have been the challenges for Indian entry to OIC, do these challenges exist anymore? What interests India wants to achieve under the umbrella of OIC?

After members' support to India, and willingness for their entry to OIC-what future beholds for the Muslims of India, for Pakistan and OIC as a whole?

\section{Significance of Research:}

The resolutions passed by OIC regarding Indian atrocities in Kashmir or towards the Muslim minorities of India have always been criticized by New Delhi and they have become vocal about that too. India aspired to be there in OIC to counter Pakistani perspective of India. This research is important in its impact, as it aims to let its reader know the other motives for why the incredible India (being the aspirant of regional hegemony) is eager to join OIC, despite the fact they have always denounced the resolutions passed by the organization. A holistic view of the situations in which India remained, managed to alter, and aims to construct is there in this respective paper. This research is significant as it narrates the tail of resilience, ambitious and firmness of stance and orientation. The research is aiming to provide an interesting view about how India managed to get into OIC, and gaining support of other members at the forum while keep sticking to its original stance.

\section{Research Methodology:}

This research paper aims to discover the answers to the above given research questions through the qualitative method. The recent trends on the issue of Indian inclusion and presence into OIC will be discussed and analysed on the basis of primary as well as secondary data. For this 
very purpose, already existing data in form of research papers, articles, newspaper stories and statements of the concerned officials will be taken into consideration.

\section{Theoretical Framework:}

Theory provides underpinning assumptions to base a research on. The concerned research topic and possible organization of the study shows that the topic has more than one layer in it. However, in order to deal with these layers, use of any single theory is not justified. Hence, two theories are being applied in this research work. First being the "Liberal Institutionalism", and the latter part of the paper is based on "Neo-Realism".

While answering to the question of challenges, theory of Liberal Institutionalism will help, as it is advocate of diplomacy and multilateralism as the most appropriate strategies to accelerate ties, avoid conflicts and work on the issues of mutual interests, and tend to champion international organizations for the same cause. This liberal theory proposes international forum as a stage for the concerned states to cooperate on the matter of their interests and also work for the human rights and betterment. So, in this case as OIC is the advocate of equal rights for the Muslims, better of Muslims around the globe and find out avenues for advanced conditions for the collective good via this international organization.

Moreover, Neo-Realism seems helpful to answer why the challenges for Indian entry into OIC does not seem to be challenges anymore, why Arab states specially Kingdom of Saudi Arabia, and United Arab Emirates along with Iran and Qatar are welcoming India into OIC, and also why India despite facing much humiliation is still eager to join OIC. The basic assumptions of NeoRealism that are given below will help reader to understand the scenario of Indo-Gulf interests.

States behave in an international anarchic system

Externally determined set of structural imperatives work as driving force for a rational state's foreign policy

States are rational unitary actors thus working for their national interests

Non- governmental, multinational and international organizations get emphasis.

7. Challenges for India: A sneak peek to the past

OIC's calling India for Kashmir and atrocities there is nothing new. India's history with respect to Organization of Islamic Cooperation is contentious, and for most of the time based on Kashmir issue. History tells the tale, where the trio of India, OIC and Pakistan engaged with each other and could never find their respective aims. The incidents are too many that give impression 
of Pakistan's influence or some sort of egoistic issues from Pakistan towards India by using the platform of OIC. However, India itself never bent down to ease the situation and abide by the instruction of OIC. Hence, India which could be the foundational member of OIC, still is "prospective observer" of the organization after passing five decades of latter's inception.

This is the tale of the challenges that halted India's way towards OIC, but at times it gives impression of India itself being the biggest challenge towards its entry into OIC. The humiliation of India in the first summit of OIC in Rabat (which is said to be intrigued by Pakistan), and a list of resolutions on Kashmir Issue and against Indian atrocities towards Muslims of India itself nullifies India's objections on OIC for being influenced by Pakistan. Pakistan always remained the biggest hurdle of India's way towards OIC, as Pakistan highlights the Indian atrocities and bad living conditions of Muslims. That is said to be the justification from Pakistan's side for why they oppose India's entry to OIC. Furthermore, for the same reason OIC has slammed India for its massacres every now and then.

Following are some incidents of Indian engagements with the OIC, and its treatment towards Muslims of India, that emerged out as a challenge for India's entry into OIC.

7.1. Rabat Summit: Humiliation that India never thought of

A lot of existing literature tells the reader that OIC being highly influenced by Pakistan refused India to attend the first ever meeting that was held in Rabat in 1969. President Yahya Khan opposed India's presence there and refused to sit with India at this forum that pressed OIC to refuse India. However, a thorough understanding of the incident is something that is not found in many readers.

It is true that India's application for the membership OIC was accepted first on the occasion of First Islamic Summit Conference in Rabat, but that appeal of representation was accepted only for the representation of a huge Muslim population there in India. Before that application was actually rejected as it was submitted by a Hindu majority state. The application when got accepted the conference had already started. It was taking time for the delegation led by Muslim leader to attend the Summit to represent Indian Muslims that made New Delhi ask a Sikh (Indian ambassador to Morocco) to represent India at OIC. The representation of Indian Muslims by a non-Muslim, while Muslims are oppressed in Ahmadabad India, came into President Yahya Khan's notice, he refused to sit at the forum with India. The argument that president gave said that 
the representation was given to the Muslims of India, not to the state of India. OIC lodged Pakistan's stance and cancelled India's presence there ${ }^{1}$.

India has not forgot the incident, and always kept slamming OIC for it is being manipulated by Pakistan, and also that OIC's resolutions are results of Pakistan's misgivings about India. However, the humiliation that India had to face in the backdrop of Ahmadabad riots is not ended yet, as it has taken the shape of criticism that India had faced and is facing because of state sponsored oppression in Gujrat, Ayodhya, Kashmir historically and curfew in Kashmir, Jamia Millia Islamia University, Aligarh Muslim University riots, and in the aftermath of Citizenship (Amendment) Act of 2019 and National Register of Citizens (NRC) India.

7.2. India and OIC's Kashmir Resolutions: Then and Now

Since five decades, India, OIC and Pakistan have not altered their respective stance. Where Pakistan keeps raising the Kashmir Issue on international forum, OIC keeps passing resolutions and asking India to allow fact finding mission to visit the valley, end the state sponsored repression and resolve the Kashmir dispute bilaterally with Pakistan, India on the other side stands still and firm with its own particular stance that OIC has no locus standi to interfere into the internal matters of OIC.

The Kashmir issue got internationalized when India took the matter to UNO. However, Pakistan left no stone unturned to raise the issue on international forum for its resolution and holding India accountable for atrocities and repression there. Pakistan raised the issue at the OIC with the intent that if more than 50 Muslim countries would speak for the matter in UN General Assembly, then it is surely going to cast an impact on the cause. ${ }^{2}$ Literature on this specific subject shows that a series of resolution on Kashmir, efforts by Pakistan and OIC were witnessed in the last decade of the $20^{\text {th }}$ century. In $19^{\text {th }}$ International Council of Foreign Ministers meeting of 1990for the first time such resolution was passed and serious concerns over the killing of the people of Kashmir were raised. The $20^{\text {th }}$ ICFM that was called by Secretary General of OIC decided to send a fact-finding mission to the Indian side of valley, but India refused to allow. The mission visited Pakistan's side of the valley and prepared a 13-pager report based on the interviews of refugees and Kashmiris. "It made strong reference to the state sponsored terror, custodial killing,

\footnotetext{
1 Abdullahil Ahsan, “OIC's India Venture: Diplomatic Achievement for India?,” Anadolu Agency, March 11, 2019, https://www.aa.com.tr/en/analysis/oic-s-india-venture-diplomatic-achievement-for-india/1414645

${ }^{2}$ A. K. Pasha, "Indo-OIC Relations Perspective and Trends-I," Journal of Peace Studies 01, no. 3-4 (1994): 02.
} 
unprovoked firing on unarmed persons, molesting of Muslim girls and other forms of torture as a policy instrument"3.

Be it Dakar Summit of 1991, Islamic Summit at Casablanca of 1994, $23^{\text {rd }}$ ICFM meeting at Kuala Lumpur of 1995 , or $8^{\text {th }}$ Islamic Summit at Tehran of 1997, 25 $5^{\text {th }}$ session of ICFM at Doha of $1998,26^{\text {th }}$ ICFM meeting at Ouagadougou of 1999 or $11^{\text {th }}$ Islamic Summit at Dakar of 2008; all these summits and meeting had a same opinion and stance that India needs to end atrocities, killing, rapes, genocides in the valley, and hold a plebiscite as Kashmiri people hold the right of selfdetermination. In addition, the resolutions possessed a sense of disappointment as India did not allow access to the valley ${ }^{4}$.

As OIC's charter and its essence talks about the solidarity of Muslim Ummah and protection of human rights, specifically Muslims around the globe, this liberal agenda pushes OIC to speak for the rights of Kashmiri people. Furthermore, on August 05, 2019 India abrogated Article 370 and 35-A which was actually stopping non-Kashmiris from owning a land in Kashmir. However, the abrogation of these articles is seen as India's attempt to alter the demography of the Valley. Moreover, he IHK is under siege, as Kashmir is under curfew for seven months. Basic facilities and needs of life are not being met. State sponsored oppression and repression is halting the people of Kashmir to live in an independent and healthy air. A complete lockdown has become the fate of the valley for past 7 months. Internet facilities are not available, due to which the exact situation, causalities, and the exact level of atrocities cannot be described. A Kashmiri anthropologist based in Massachusetts Muhammad Junaid calls this situation as "military siege". What Junaid has more to say was, "Entire streets are blocked. They cannot communicate with each other"5

Historically, India has been criticized and its own acts turned out as a challenge. Pakistan and its narrative still are and will remain a challenge, but what is important is that a shift in the overall picture of OIC is evident. India remained firm in her stance over Kashmir, claiming it as internal matter of India. However, the Kashmir cause seems to be sabotaged by the intra OIC

\footnotetext{
3 Saira Orakzai, "Organization of the Islamic Conference and Conflict Resolution: Case Study of the Kashmir Dispute," Pakistan Horizon 63, no. 2 (2010): 89-92.

${ }^{4}$ Saira, "Organization," 89-92.

5 MEE Staff, "An affront to Muslims: OIC Slams India's crackdown on Kashmir," Middle East Eye, August 14, 2019, https://www.middleeasteye.net/news/india-condemned-violating-kashmiri-muslim-re ligious-rights
} 
politics, and the implications of the shaken Muslim unity can be seen when Pakistan's call for a meeting to condemn Indian violence is denounced by the member states.

OIC raised objections on the abrogation of the Article 370 and 35-A by New Delhi, simultaneously asked both India and Pakistan to resolve the issue bilaterally. Amid aggravated fury in Pakistan over increased violence in IHK, OIC slamming and objecting India for its deeds, powerful OIC countries like Kingdom of Saudi Arabia and UAE don't seem to support Pakistan's stance, and they have called it "internal matter of India". Russia who enjoys the observer status in OIC supported India's stance while Russian foreign minister said, "We proceed from fact that the changes associated with the change in the status of the state of Jammu and Kashmir and its division into two union territories, are carried out within framework of the Constitution of the Republic of India". Russia added that India and Pakistan should "not allow aggravation of the situation in the region due to the change by Delhi in the status of the state of Jammu and Kashmir"6

The argument here is that India's human rights violations, and Pakistan's concerns remained as a challenge for India's approach to OIC. These concerns are here to stay. OIC will keep condemning and criticizing India over its atrocities but the intensity of the challenges is not same as powerful OIC states has soften their approach and started to weigh their stance and statements regarding India. The reasons for this sort of behavior will be elaborated well in the latter part of the paper.

7.3. Ayodhya (Babri Masjid) Issue: Then and Now

Where on one side the last decade of $20^{\text {th }}$ century saw OIC's critical stand point over Kashmir, at the same time Ayodhya incident was another matter of concern for OIC. OIC was the first to raise the concerns over the deterioration of the Babri Masjid, criticized this act and urged India to restore Muslim's shrine in its original condition. OIC left no stone unturned and used many forums to record their protest and anguish. In addition, the level of furry in OIC urged it to impose an oil embargo on India. OIC nations showed their outrage at United Nations where they asked United Nations' Secretary General Dr. Ghali to use his political and moral authority to ensure safety and security of Muslims of India. They were eager to raise the issue at the next session of UNHRC. OIC demanded from India full protection of the lives and property of Muslims

\footnotetext{
${ }^{6}$ Prabhash K Dutta, "Kashmir: Pakistan tries to isolate India over Article 370, gets a reality check," India Today, August 12, 2019, https://www.indiatoday.in/news-analysis/story/kashmir-pakistan-tries-to-isolate-india-overarticle-370-gets-a-reality-check-1579988-2019-08-12
} 
of India. In December 1992 more than 50 IC countries met Dr. Ghali and again conveyed their pain and torment over the matter. India did not like the move. Mr. R.L. Bhatia who was the former Minister for External Affairs of India met OIC ambassadors in New Delhi and reiterated that Ayodhya issue is India's internal matter. These ambassadors were from Iran, Iraq, Egypt, Jordan, Indonesia, Malaysia, Senegal, Uganda, Morocco, and Brunei.

Later on OIC countries were surprised to know that Hindus were given permission to perform their religious obligations where the Babri Masjid was demolished. A draft resolution was prepared which was highly influenced by Pakistan and it condemned India in strong words but PLO's chairperson Yasser Arafat and Senegalese President Abdon Diouf adopted moderate approach. While the bureau of OIC asked India to protect the Muslims of India, New Delhi's response was savage as the spokesperson said, "India needs neither advice not exhortation in regards to the protection of the human and religious rights of its Muslim minority numbering over 100 million"'

On November 09, 2019 the Supreme Court of India finally gave their decision that the 460 years old Masjid after the demolition of the Hindu temple there. The place in the birth place of Rama and belongs to the temple. So a Hindu temple is to be built there. OIC expressed their concerns at the happening. Soon after the decision, Pakistan reported the decision to OIC ambassadors in Pakistan and OIC issued a statement on social networking site Twitter mentioning OIC's concerns regarding the Ayodhya case. "The Secretary General of Organization of Islamic Cooperation has been closely following recent developments affecting Muslim minority in India. The body expresses its concerns over pertaining to both the issues of citizenship rights and the Babri Masjid case"8.

Hence the structure of the engagements remains same over the years where Pakistan is still holding the issue of anti-Muslim decisions, riots and communal violence of India. Pakistan wants India to pay heed towards the matter and stop promoting RSS ideology. Pakistan keeps pushing OIC to condemn these brutalities of India against Muslims residing there. It can be the case that Pakistan is raising these issue as a part of its hostile relationship with India. And wants OIC countries to condemn India on international level. Interestingly, if the case is so, still India itself

\footnotetext{
${ }^{7}$ A. K. Pasha, "Indo-OIC Relations Perspective and Trends", Journal of Peace Studies 1, No. 3-4 (1994): 05-08.

${ }^{8}$ The Economic Times, "OIC expresses concerns over CAA: says "closely" following developments," The Economic Times, December 23, 2019, https://economictimes.indiatimes.com/news/politics-and-nation/oicexpresses-concern-over-caa-says-closely-following-developments/articleshow/72931689.c ms ?fro m=mdr
} 
providing such chances to the world specifically Pakistan and emerging as a challenge for itself, and being reason for its strained ties with OIC.

\subsection{Communal Violence against Muslims in India:}

Communal violence against Muslims in India is nothing new. The world saw anti-Muslim violence in the beginning of $21^{\text {st }}$ century in Gujrat. Nothing different is happening now in other Indian states in the aftermath of Citizenship Amendment Act. The act allows the followers belonging to six religions including Christianity, Hindu, and Sikh, excluding Muslim- to get the nationality of India provided they have been living here in India for about six years and had left their home country because of anti-religion persecution. Muslims in India having concerns regarding this particular act started protesting in many states. The Muslim students of Jamila Millia Islamia, Nadwa University, Aligarh Muslim University of Uttar Pradesh and Maulana Azad Urdu University of Hyderabad protested. Ironically the peaceful protestor were beaten, bashed and victimized by teargas shells. Related videos went viral on social media. State sponsored repression took lives of hundreds of people and many were injured. Petitions were filed in the court as protestor hold the stance that the concerned act is against Article 14 of Indian Constitution that gives rights to citizens of India regardless of their religion.

The intensity of the issue was not minimized fully and the world saw another episode of brutality against Muslims in India. This time BJP leader Kapil Mishra after losing his seat in the election sparked the violence as Mishra provoked the Hindu mob to viciously remove a group of Muslim people who were blocking street as protest against CAA. Stone pelting started afterwards, and soon the fire reached the entire city. Muslim are being lynched by violent mobs, their houses, masjids are being burnt. Muslims are beaten inhumanely. This is the behavior and repression Pakistan always condemned and made base for opposing India's entry to OIC. Where at one place Major OIC countries are establishing bilateral ties with India, Pakistan is pushing OIC to condemn India and urging India to protect Muslims. India as criticized OIC being highly influenced by Pakistan, has always created reasons for Pakistan to base its stance on. On the other hand India emerged as a challenge for its own entry to OIC where neither it abides by the resolution passed by OIC, nor allows OIC to comment on the issues regarding Muslims of India entitling them as 'Internal Matter".

As a response to the Delhi riots 2020, OIC issued a statement that said "Condemns the recent and alarming violence against Muslims in India, resulting in the death and injury of innocent 
people and the arson and vandalism of mosques and Muslim-owned properties." India's Minister of External Affairs Raveesh Kumar denounces these claims made by OIC in this latest statement, and claimed that this is not reality based and inaccurate, as India is trying to restore normalcy. ${ }^{9}$

Pakistan has always been critical towards India, while OIC is also issuing statement as an organization. However, these statements have not remained impactful as these used to be because Kingdom of Saudi Arabia and UAE don't seem to be bothered by what is happening to the Muslims in India, while they pursue their respective bilateral economic and strategic interest with India. These are interests on part of India, for why she wants entry to OIC, while on the other hand rebuts OIC. Interests of major Gulf States are pushing them to overcome challenges in the way of Indian entry to OIC.

\section{India's Interest in OIC:}

The Republic of India is the ambitious state and aspirant of regional hegemony. She has stuck to her stance on Kashmir, her own narrative regarding the issue and stand tall in front of OIC and its resolutions. Even rebuts OIC whenever finds anything against it. Yet at the same time India wants to be there in OIC and India believed its presence in the $46^{\text {th }}$ ICFM meeting at Doha (despite Pakistan's opposition) as victory. India was amused when OIC members turn deaf ear to Pakistan concerns and share the views that the world specifically OIC has realized India's importance. Here lies the question that despite the India's humiliation caused by OIC, many resolutions against India on Kashmir issue, and when India finds OIC speaking non-sense and highly manipulated by Pakistan; why India still wants to be there in OIC? Why India is amused with the first ever session in the five decades? What is pushing India to establish links with OIC regardless of a bitter past?

To answer these queries, there is required a clear understanding of India's foreign policy objectives. Author Vinay Barkane in his article "India's Strategic Interests in West Asian Region" elucidates the shift in India's post-cold war policy structure, as new Prime Minister P.V. Narishma Rao was ambitious. Rao foreign policy objectives like national interests- oriented pragmatism, economic liberalization replaced protectionism and aimed at enabling India to join the mainstream economic powers. For that matter they started to look at the gulf region and East Asia with new thinking. Same goes for the current Prime Minister Modi as he wants to make India get "Great

\footnotetext{
9 The Economic Times, "Delhi riots: India rebuts charges made by OIC," The Economic Times, February 27, 2020, https://economictimes.indiatimes .com/news/politics-and-nation/delhi-riots-india-rebuts-charges-made-byoic/articleshow/74335616.cms
} 
Power Recognition" and for that matter gets engaged with big powers. He looks at a multipolar world with India being the important power of this power structure. They aim at becoming economic giant. Additionally, India desires a clear image of the country and to be praised and recognized as great power.

There are some reasons why India wants to be there in OIC. These include:

To clear its bad image specifically in regard to atrocities against Muslims

Counter Pakistan influenced narrative

Recognition as an important big power

Strengthening ties with Gulf countries as part of their economic policy

India has tried to establish friendly ties with OIC as in 1994, the Secretary of Ministry of External Affairs of India, Salman Haider invited OIC to send its officials to visit New Delhi as the first step towards normalcy of ties. Before that Mr. Ishrat Aziz who was Indian ambassador to Riyadh paid a visit to OIC headquarters too. The main motive of this invite was to being a balancing touch in India-OIC ties, and persuade OIC to tone down regarding India.

India has remained vocal about its deteriorating image because of OIC's resolutions and specifically Pakistan. New Delhi takes the stance that the organization promotes and works on Pakistan's agenda, and highly influenced by what Pakistan thinks of India. Their resolutions are highly biased thus damaging India's image and portraying a deteriorated picture of India to the outer world. As in response to OIC's tweet about its concerns regarding the state of Indian Muslims during Delhi riots of 2020, MEA Raveesh Kumar issued a statement and called OIC's statement as inaccurate, selective and misleading ${ }^{10}$.

India also slammed OIC in June 2019 when OIC issued Final Communique discussing Jammu and Kashmir. It was held in Makkah. MEA Raveesh Kumar said, "OIC should refrain from making such unwarranted references". And rejected OIC's reference as "unacceptable"11. That is how India has been remained concerned about its image and this adds to the reasons for why New Delhi is eager to be there at OIC. By the help of their presence, New Delhi can counter Pakistan's perspective, give their stance on the issue, and refrain OIC from passing further resolution against

\footnotetext{
${ }^{10}$ Delhi riots: India rebuts charges made by OIC, The Economic Times, February 27, 2020, https://economictimes.indiatimes.com/news/politics -and-nation/delhi-riots-india-rebuts-charges-made-byoic/articleshow/74335616.cms

11 The Economic Times, "India slams OIC for references to J-K in its Makkah Summit Declaration," The Economic Times, June 03, 2019, https://economictimes.indiatimes.com/news/politics-and-nation/india-slams-oicfor-references-to-j-k-in-its-makkah-summit-declaration/articleshow/69638750.cms
} 
India and meddling into internal affairs of India. Furthermore, OIC is the second largest organization after UNO and India realized the need to be their being aspirant of hegemony, so that she may influence the decisions there.

\subsection{Economic Interests:}

Vinay Barkane in his article 'India's Strategic Interests in West Asian Region" realizes that India has good ties with G.C.C. states and the relations are strained with OIC because of its resolutions on Kashmir. The answer to the question why India is so vocal about its ties Gulf States, is because India is important economic and strategic partner of major Arab countries like KSA, UAE and Qatar. India's interest is to be even closer with these states, and OIC presents the best possible platform to diversify the extent of this already multilateral relationship. According to the stats of 2017, approximately 3,050,000 Indians live and work in KSA while 2,800,000 in UAE. This level of people-to-people contact and interests in trade, energy and strategy is enhanced since Prime Minister Modi has come to power. West Asia is important for India as India gets 58pc of oil and 88pc of liquefied gas from Gulf. ${ }^{12}$

Rightly acting according to the theory of neo-realism that states; states pursue their national interests and thus act rationally. This is the pragmatism India and some of other Arab states base their behaviour on. However, India wants closer ties with Arab states to expand trade and strategic ties with them. Indian Ministry of Commerce released statistics in 2018 which show that India traded of US\$ 267 billion with OIC countries, of which \$91 billion were of exports and \$172 billion were of imports. UAE is India's top trading partner while other Gulf States constitute around more than $31 \mathrm{pc}$ of India's trade. ${ }^{13}$

Mukesh Ambani, the richest man of India and the owner of Reliance Industries Limited (RIL) has announced that Saudi Aramco is going to get $20 \mathrm{pc}$ stakes into RIL. ${ }^{14}$ These sort of economic engagements are nothing new but started in accelerated in mid-2000. As in 2004 Saudi Aramco's Abdullah S Jum'ah and Exxon Mobile's Rex Tillerson (former Secretary of State) met in Goa. The leaders promised to stand by India's energy needs. In 2003 Indian President A.P.J.

12 Vinay Barkane, "India’s Strategic Interests in West Asian Region," LHFHM-17, October 2017, http://eirai.org/images/proceedings_pdf/DIRH1017021.pdf

13 Shafeeq Rahman, "India can Ignore OIC- for now", Asia Times, August 30, 2019, https://asiatimes.com/2019/08/india-can-ignore-oic-on-kashmir-for-now/

14 Bilal Kuchay, "Why have Saudi Arabia, UAE failed to condemn India over Kashmir", Aljazeera, September 12, 2019, https://www.aljazeera.com/news/2019/09/saudi-arabia-uae-failed-condemn-india-kashmir-

190911112648176.html 
Abdul Kalam visited Saudi Arabia and in 2006, late King Abdullah bin Abdul-Aziz al Saud visited India. Delhi Declaration and Riyadh declaration ware the documents of their bonhomie. ${ }^{15}$

\subsection{Strategic Interests:}

Western side of Indian Ocean is of huge importance for India. As India is the aspirant of regional hegemony and have contentions with China on many issue. India is highly concerned about China's naval activities and PLA's strategic presence in Indian Ocean Regions. New Delhi finds it important to have strengthened geopolitical ties with Gulf countries and Gulf Navies to ensure its presence in the region. India is a beneficiary of the trade flows of West Asian littorals. Moreover, Iran also looks for such support in order to control the Western approaches to Arabian Gulf. India provides such support. In 2005, the forces of Indian Air Force visited Saudi Arabia for the first time. In 2018, India and UAE got engage in joint naval exercises too.

\subsection{Diplomatic Interests:}

India needs support at international forums and specifically when it comes from Pakistan's allies, at the time when they support India by turning a deaf ear to Pakistan- this is of critical importance to India. However, India finds it, her diplomatic victory which she wants to enjoy time and again. Some of prominent OIC countries have remained in support of India joining OIC like Qatar, UAE, KSA and recently Bangladesh in 2008. Saudi crown Prince visited India after two days visit to Pakistan in February 2019. In addition, UAE invited India to the $46^{\text {th }}$ session of ICFM as "Guest of Honor". The mutuality of economic and strategic interests among India and these Arab countries will get New Delhi the diplomatic support on International forums like OIC and also in UN when other OIC member states will raise their voice against India and Indian atrocities against Muslims of India.

However, these interests are urging major Arab countries support India's presence at OIC and refraining OIC from conducting meeting to criticize India for their state sponsored repression in Jammu and Kashmir. Hence, India's efforts to establish warm ties with Arab nations are yielding fruit.

15 Kabir Taneja, "Why Saudi Arabia and UAE are not bothered by India's Citizenship Amendment Act", The Diplomat, January 16,2020, https://thediplomat.com/2020/01/why-saudi-arabia-and-the-uae-arentbothered-by-indias-citizenship-amendment-act/ 


\section{Indo-Arab Ties yielding Fruit:}

February 2019 saw an escalation and heightened tensions between conventional rivals, in the aftermath of Pulwama attack. Pakistan was surely to raise the issue in the OIC's $46^{\text {th }}$ session of ICFM where Foreign Minister Shah Mehmood Qureshi was supposed to represent Pakistan. The session was going to be held at Doha in March 2019. UAE invited India to the meeting as "Guest of Honor". Pakistan protested, but efforts went in vain. That resulted in the absence of Foreign Minister Qureshi from the meeting, while a low level delegation represented Pakistan.

KSA and UAE didn't bother about Pakistan's concerns and this was speculated as a diplomatic victory of India by Indian media outlets. They claimed it as revenge of the humiliation that India had to face in Rabat Summit of 1969. The tale of cordiality is not over yet, as UAE presented Indian Prime Minister Modi with the highest civil award at the time when Pakistan took the position that Kashmir is under military siege and there is required a voice for the solidarity and protection of Muslims there.

Saudi Arabia expressed their concerns about India scrapping the special status of Kashmir unilaterally, while United Arab Emirates called this matter as internal matter of India. In addition, Qatar, Bahrain, Oman and Kuwait seemed reluctant to issue a statement. The $\$ 100 \mathrm{bn}$ investment with UAE won over the human rights, which is rightly going on the structure based on neo-realism. Moreover, the leaders of Middle East remained quiet when India introduced Citizenship Amendment Act and the whole world considered the act as damaging to India's secular image, thus having pejorative bias towards Muslims of India. Once again the matter was considered as internal to India. While the hymns of Muslim solidarity remained inaudible.

Furthermore, in December 2019, Pakistan asked OIC to call a meeting of Foreign Minister's level. At the time when Pakistan was all set to attend Malaysia Summit in December 2019, it was seen as a contrary forum to OIC and Pakistan, and Pakistan was stopped to attend the summit. Soon after the happening, Saudi Foreign Minister Faisal bin Farhan visited Pakistan and indicated to conduct such a meeting. However, what Indian media called as "Snubbed", Pakistan was snubbed and refused. Kingdom went back on its words and refused to call Foreign Minister Level meeting on Kashmir.

Hence, the Indo-Arab bonhomie has started to reap fruits and the entire setback lies for Pakistan, where Pakistan is committed to its stance over Kashmir, and other concerns regarding atrocities against Muslim in different parts of India. While on the other hand Arab world and major 
OIC members are short of words to even issue a statements. The cause of Muslim solidarity is suffering because of geopolitical, and geostrategic realities and interests. Wealthy Arab nations are aiming at their national interests. Paksitan in all this scenario has been side lined. OIC has continued to lose its original motive and failing on its criteria- courtesy major Arab members of OIC. However, if this the situation where even Bangladesh is advocating to give India observer status in OIC, what future beholds for OIC? Is it going to lose its essence of Muslim solidarity? Is the organization which aimed at protection of Muslims of the world, will be hanged to death because of member's national interests. Will Pakistan compromise its stance?

\subsection{Future Prospects:}

Initially India faced challenge to approach OIC, faced humiliation and many resolutions passed by OIC over Kashmir Issue. However, India by sticking to its original stance, diplomatically played in a skilful manner. This diplomatic, political, economic and strategic win of India has put Pakistan in hot waters, and in a situation where questions are arising on Pakistan's diplomacy. Knowing of Pakistan's weak economic structure and dependence over Saudi Arabia, and its bonhomie with Arab states it is easy to find out why Saudis and Emiratis are inclined towards India. India has been recognized as a big power that cannot be ignored anymore. Possibilities and alternatives lie here about what can be the future of OIC. The possible futuristic structure of OIC

May have India as an observer thus making Pakistan dis-comfortable with India's presence. OIC (specifically KSA and UAE) impose conditions on its bilateral ties with Pakistan and press Islamabad for accepting India's presence in this Islamic organization.

There is possibility that OIC don't alter its structure because of Islamabad's concerns over New Delhi's treatment to Muslims across the state and in Indian held Kashmir. However, Indo-Arab ties will continue to reap fruits of their bonhomie in bilateral terms. OIC will keep issuing statement as an institution and India will keep rebutting OIC's statements effortlessly, knowing that major economic powers of OIC are its allies.

Possible future resolutions against India will be curtailed by India's allies in OIC.

The fragmentation of OIC is a possibility that cannot be avoided. India's already aware of what significance OIC has in international arena. Only India cared about OIC because of their united power in UNO. If they voiced together against India in UNO- that would have casted an impact. India is unperturbed as it knows that the members of OIC-the Islamic organization which 
chants for the unity of Muslims across the globe, is unable to maintain the unity among the member states, for instance Iran and Saudi Arabia. New Delhi is well aware of the differences of Muslim world and also their respective interests. India has played on it successfully. The organization may get fragmented in two factions. One who don't support India's presence, atrocities against Muslims and cordial behavior of other states towards New Delhi (e.g. Pakistan, Malaysia, Turkey); and the other faction who wants India to be as an observer in OIC and reaping fruits of mutuality of interests (e.g. Kingdom of Saudi Arabia, United Arab Emirates, Qatar and Bangladesh).

Most likely prospect of the OIC is that the organization may continue with it structure and stance and keep issuing statements against Indian atrocities. Additionally, Riyadh not pressing Pakistan over India's inclusion and not causing anguish in Islamabad as latter is important part of the organization being the only Muslim nuclear power, and Riyadh depends on Pakistan's forces to protect the two Holy cities. Hence, Riyadh and Abu Dhabi will continue their bilateral engagements with New Delhi while New Delhi knowing that there is nothing to be worries about. 10. Suggestions:

However, whatsoever the structure be, Pakistan needs to diversify its ties with other Muslim countries like Turkey and Malaysia and lessen its dependence on Saudi Arabia. That will help Pakistan to get support against Indian atrocities towards Muslims and specifically Kashmir. India could get the support because of firmness of its stance and engaging in bilateral and mutually beneficial projects. While Pakistan suffers due to the conditions and provisions on its dependence over the aid which it gets from Riyadh. In order to beat India's economic, political and diplomatic clout, Islamabad needs to stand by its stance and diversify its diplomatic and political clout. Islamabad can utilize other forums like Malaysia Summit to press Riyadh, and call for a meeting. Islamabad needs to thebe aware of the advancement and swiftness of the ties and the respective consequences. As the more independent policies Pakistan will pursue, the more its stance will be able to get honour and earn dignity to Islamabad. Islamabad needs to look for new friends while strengthening and diplomatically playing with the older ones.

The leadership needs to understand that only a few counties are stick to OIC's original essence and of which mainly Pakistan is raising the issue of Indian atrocities. The leadership need to realize the new tactics of geopolitical, geostrategic engagements and diplomatic engagements. One more thing that is required to be considered is a realization that in order to earn dignity and honour along with universal support of one's stance, a nation has to lose much. This loss can be 
of some economic benefits, some political setbacks and damaging of image for some time. However, the eye should be on the greater goal to stand still, firm and clear in its objectives and never compromise on national interests. For instance, India had to face backlash, damage to its image, but the firmness of its stance and reluctance to give up on its national interests, belief in it strength, utilize all its capabilities and pursue independently and diplomatically in a skilful manner has earned India the support it is getting and the posture it is portraying as a stiff big power. It took years for India to achieve this position and turn the challenges to approach OIC into opportunities. Furthermore, Pakistan is already a strong nation, rare in history but Civil and military leadership is on same page with the nation having leadership's back; Pakistan is capable of much more. However, what it requires is a will power to stand independently, pursue independent policies, strengthening economy, readiness to lose something to earn dignity in international arena.

\section{Conclusion:}

OIC never had something good for India. Starting from its foundational meeting till to date, India has been the point of concern for OIC and specifically for Pakistan. OIC charter where does not allow any state to become member that has conflict with other member state, allowed for representation of Indian Muslims, but things didn't go well. Indian atrocities against Muslim and Kashmir being the bone of contention between India and Pakistan- emerged out as a challenges for India to approach OIC. India realizing the real importance of OIC, diplomatically approach the powerful economic members of OIC and gained support that can be used to snub Pakistan at times. India has changed the challenges into opportunities that earned her presence in OIC's $46^{\text {th }}$ ICFM meeting in 2019. However, the real challenge that had been and continues to be is Paksitan and its concerns regarding Indian Muslims and Kashmir. Pakistan can play as a constraint for India in OIC only if strengthens its overall stature as a stature as a state. Indian atrocities are here to stay, and in order to oppose them in OIC, Pakistan needs to earn the strength of stance and verdict. Knowing Pakistan as the major constraint and challenge in India's path to OIC, where India has approached OIC members in other ways, simultaneously has created challenges for the unity of OIC, presence of the organization and also for the importance of Pakistan's stance over Kashmir. India has turned the game on Pakistan, while Pakistan having all the capabilities and strength to remerge is to work a lot to continue to stay as a challenge for India into OIC, else other allies of India which are also the members of OIC are in support to get her into OIC, thus pushing Pakistan to the wall and creating challenges for Pakistan. 
Bibliography

Ahsan, Prof. Abdullahil. 2019. Anadolu Agency. March 11. Accessed February 28, 2020. https://www.aa.com.tr/en/analysis/oic-s-india-venture-diplomatic-achievement-forindia/1414645.

Anonymous. 2019. India Today. March 02. Accessed February 28, 2020.

https:/www.ind iatoday.in/education-today/gk-current-affairs/story/oic-2019-is lamic-summitindia-invited-first-time-sushma-swaraj-1468689-2019-03-02.

—. 2019. Manohar Pakrikar IDSA. March 25. Accessed February 28, 2020.

https:/idsa.in/idsacomments/india-at-the-oic-chinoy-quamar-250319.

Arora, Rhea. 2019. QRIUS. February 26. Accessed February 28, 2020. https://qrius.com/indiabecomes-first-non-islamic-nation-to-attend-oic-find-out-what-this- means/.

Cavalli, Giacomo. 2009. "The New Organization of the Islamic Conference." Perspective on Federalism 134-139. Accessed February 28, 2020. http://on-

federalism.eu/attachments/016_download.pdf.

Chaudhury, Dipanjan Roy. 2019. The Economic Time. March 06. Accessed February 28, 2020. https://economictimes.ind iatimes.com/blogs/et-commentary/india-at-oic-summit-a-brid ge-overtroubled-waters.

Dutta, Prabhash K. 2019. India Today. August 12. Accessed March 06, 2020.

https:/www.ind iatoday.in/news-analysis/story/kashmir-pakistan-tries-to-isolate-india-overarticle-370-gets-a-reality-check-1579988-2019-08-12.

Hassan, Saad. 2020. TRT World. February 07. Accessed March 08, 2020.

https $/ /$ www.trtworld.com/asia/another-setback-for-pakistan-s-faltering-kashmir-stance-33584.

Khatu, Jayesh. 2019. The Diplomat. March 05. Accessed February 28, 2020.

https:/thed iplomat.com/2019/03/india-at-the-oic-has-history-been-made/.

Kuchay, Bilal. 2019. Aljazeera. September 12. Accessed March 08, 2020., https:/www.aljazeera.com/news/2019/09/saudi-arabia-uae-failed-condemn-ind ia-kashmir190911112648176.html.

Mehta, Ketan. 2019. Observer REsearch Foundation. October 14. Accessed February 28, 2020. https:/www.orfonline.org/expert-speak/oic- views-kashmir-india-achilles-heel-islamic-world$56584 /$. 
Rahman, Shafiq. 2019. Asia Times. August 30. Accessed February 28, 2020.

https://asiatimes.com/2019/08/india-can-ignore-oic-on-kashmir-for-now/.

Staff, MEE. 2019. Middle EAst Eye. August 14. Accessed February 28, 2020.

https:/www.middleeasteye.net/new s/ind ia-condemned-violating-kashmiri-muslim-religiousrights.

Taneja, Kabir. 2020. The Diplomat. January 16. Accessed March 08, 2020.

https:/thed iplomat.com/2020/01/why-saudi-arabia-and-the- uae-arent-bothered-by-indias-

citizenship-amendment-act/. 